\title{
In Vitro Study of Antimicrobial Activity of Acalypha Indica Linn. Extract
}

\author{
Farah Dayana Ishak ${ }^{1}$, Siti Zaiton Mat So' ad ${ }^{1,}$, Anis Hazirah Asmali Jauhari ${ }^{2}$, Nini Nadira Mashud ${ }^{2}$ \\ and Norazian Mohd Hassan ${ }^{1}$ \\ ${ }^{1}$ Kulliyyah of Pharmacy, International Islamic University Malaysia, 25200, Kuantan, Malaysia \\ ${ }^{2}$ Kulliyyah of Science, International Islamic University Malaysia, 25200, Kuantan, Malaysia
}

\begin{abstract}
The objective for this research undertaken was to evaluate Acalypha indica extracts for their antimicrobial potential. Fresh plant samples were extracted via maceration in increasing polarity using petroleum ether, chloroform and methanol. Antimicrobial activity of the extracts was assessed using disc diffusion assay and minimum inhibitory concentration. It was observed that the crude methanol leaves, stembark and chloroform stembark extracts exhibit antimicrobial activity towards both Staphylococcus aureus bacteria and Candida albicans fungi. The inhibition zones recorded in milimeters by the chloroform stembark extracts were $9.57 \pm 0.51(200 \mathrm{mg} / \mathrm{mL}), 8.33 \pm 0.58(100 \mathrm{mg} / \mathrm{mL}) \mathrm{and}$ $7.33 \pm 0.58(50 \mathrm{mg} / \mathrm{mL})$ while methanol stembark extract recorded inhibition zones at $13.67 \pm 0.58(200 \mathrm{mg} / \mathrm{mL})$, $10.00 \pm 1.00(100 \mathrm{mg} / \mathrm{mL})$ and $9.33 \pm 0.58(50 \mathrm{mg} / \mathrm{mL})$ against $S$. aureus. Antifungal activity was also detected against $C$. albicans as the chloroform stembark extract produced inhibition zones of $14.33 \pm 0.58(200 \mathrm{mg} / \mathrm{mL}), 13.33 \pm 0.58(100$ $\mathrm{mg} / \mathrm{mL})$ and $12.67 \pm 0.58(50 \mathrm{mg} / \mathrm{mL})$ while the methanol stembark extract resulted in inhibition zones of $15.33 \pm 0.58(200$ $\mathrm{mg} / \mathrm{mL}), 14.33 \pm 0.58(100 \mathrm{mg} / \mathrm{mL})$ and $13.0 \pm 0.00(50 \mathrm{mg} / \mathrm{mL})$. In the case of crude methanol leaves extract, the extract produced inhibition zones of $19 \pm 0.58(200 \mathrm{mg} / \mathrm{mL}), 13 \pm 1.00(100 \mathrm{mg} / \mathrm{mL})$ and $10 \pm 1.00(50 \mathrm{mg} / \mathrm{mL})$ against $S$. aureus while against $C$. albicans, the extract recorded inhibition zones of $15 \pm 0.58(200 \mathrm{mg} / \mathrm{mL}), 14 \pm 0.00(100 \mathrm{mg} / \mathrm{mL}) \mathrm{and}$ $13 \pm 0.00(50 \mathrm{mg} / \mathrm{mL})$. The chloroform stembark crude extract developed a medium MIC value of $0.938 \mathrm{mg} / \mathrm{mL}$ while both methanol crude extracts produced a strong MIC value of $0.469 \mathrm{mg} / \mathrm{mL}$ during the minimum inhibition concentration screening against Candida albicans.
\end{abstract}

Keywords: Euphorbiaceae, Acalypha indica, Antimicrobial.

\section{INTRODUCTION}

The derivation of plants to produce drugs is basically bound to a principle which describes the potential of breaking plants down, isolating their active components and producing powerful drugs in standard form. Thus, to design drugs from medicinal plants of interest, it is crucial to research certain aspects of the plant itself. One of these areas is pharmacognosy. As such, the Acalypha is one of the genuses that show a great potential in the world of scientific advancement due to its promising chemical and biological results.

Acalypha indica Linn. (Euphorbiaceae) also known as 'kucing galak' is widely distributed throughout tropical Africa and South Africa, India and Sri Lanka, as well as Yemen and Pakistan. It is a monoecious plant with a weedy nature, annual to sometimes short-lived perennial herb that can grow up to 1.5 to $2.5 \mathrm{~m}$ tall [1]. A. indica are popularly utilized as herbal medicine in the Indian Ocean islands as well as in India for its expectorant properties. The main parts that are usually exploited in medicine are the roots, leaf, stalk and flowers. The plants are emetic, expectorant, laxative and diuretic. It is useful in bronchitis, pneumonia

*Address correspondence to this author at the Kulliyyah of Pharmacy, International Islamic University Malaysia, 25200, Kuantan, Malaysia; E-mail: dszaiton@iium.edu.my and pulmonary tuberculosis. A. indica also contains several alkaloids as well as hydrocyanic acid which can be deadly in the wrong dose, but young shoots are also eaten as vegetable [1].

The plant extract is considered to have antidiabetic in accordance to a research involving normal rats and alloxan induced diabetic rats [2]. A. indica is also known to possess respiratory effect on experimental animals such as bronchodilation and bronchial hyperreactivity. The end result of this particular study was that it has beneficial effect in asthma [3]. Another potential attribute of the A. indica is that it has antioxidant effect and should be implemented in a diet to control diseases where free radicals are involved.

\section{MATERIALS AND METHODS}

\section{Preparation of Extracts}

The Acalypha indica plant was collected from Tasik Chini, Pahang. It was authenticated by a plant botanist from Universiti Kebangsaan Malaysia. About $5 \mathrm{~kg}$ of finely powdered dry stem bark and leaves were soaked with petroleum ether, chloroform and methanol. The soaking process was repeated three times for each solvent. The solvent extracts were filtered and evaporated under vacuum at $55^{\circ} \mathrm{C}$ to yield the respective crude extract. The crude extracts were transferred into sample bottles and kept in refrigerator prior to use. 
Table 1. Antimicrobial Activity of Different Crude Solvent Extracts of Acalypha Indica

\begin{tabular}{|c|c|c|c|c|c|c|}
\hline \multirow{2}{*}{ Extracts } & \multirow{2}{*}{ Concentration $(\mathrm{mg} / \mathrm{ml})$} & \multicolumn{5}{|c|}{ Inhibition Zone (mm) } \\
\hline & & S.a & P.a & E.c & C.a & T.t \\
\hline \multirow{3}{*}{ Chloroform (stembark) } & 200 & $9.57 \pm 0.51$ & - & - & $14.33 \pm 0.58$ & - \\
\hline & 100 & $8.33 \pm 0.58$ & - & - & $13.33 \pm 0.58$ & - \\
\hline & 50 & $7.33 \pm 0.58$ & - & - & $12.67 \pm 0.58$ & - \\
\hline \multirow{3}{*}{ Methanol (stembark) } & 200 & $13.67 \pm 0.58$ & - & - & $15.33 \pm 0.58$ & - \\
\hline & 100 & $10.00 \pm 1.00$ & - & - & $14.33 \pm 0.58$ & - \\
\hline & 50 & $9.33 \pm 0.58$ & - & - & $13.00 \pm 0.00$ & - \\
\hline \multirow{3}{*}{$\begin{array}{c}\text { Petroleum ether } \\
\text { (stembark) }\end{array}$} & 200 & - & - & - & - & - \\
\hline & 100 & - & - & - & - & - \\
\hline & 50 & - & - & - & - & - \\
\hline \multirow{3}{*}{ Methanol (leaves) } & 200 & $19.00 \pm 0.58$ & - & - & $15.00 \pm 0.58$ & - \\
\hline & 100 & $13.00 \pm 1.00$ & - & - & $14.00 \pm 0.00$ & - \\
\hline & 50 & $10.00 \pm 1.00$ & - & - & $13.00 \pm 0.00$ & - \\
\hline Nystatin & & - & - & - & 25.00 & 32.00 \\
\hline Tetracycline & & - & 32.00 & - & - & - \\
\hline Ampicillin & & 18.00 & - & 25.00 & - & - \\
\hline
\end{tabular}

No activity; S.a, Staphylococcus aureus; P.a, Pseudomonas aeruginosa; E.c, Escherichia coli; C.a, Candida albicans; T.t, Trichophyton tonsurans

\section{Antimicrobial Screening}

\section{Microorganisms}

The microorganisms used in this present study were bacteria (Staphylococcus aureus, Pseudomonas aeruginosa ATCC 27853, Escherichia coli ATCC 25922) and fungi (Candida albicans, Trichophyton tonsurans ATCC 28942). Bacteria and fungi were cultured maintained on Mueller Hinton Agar (Merck, Germany) and Sabouraud's dextrose agar, SDA (Difco, USA) respectively at $25^{\circ} \mathrm{C}$.

\section{Preparation of Standardized Microbial Suspension}

Stock cultures were prepared and maintained at $4^{\circ} \mathrm{C}$ in Mueller Hinton Broth (MHB) and Sabouraud Dextrose Broth (SDB) cultures. Standardized microbial inoculums was adjusted to $0.5 \mathrm{McF}$ arland and then diluted to $1 \times 10^{8}$ $\mathrm{CFU} / \mathrm{mL}$ [4].

\section{Disk Diffusion Method}

An antimicrobial assay was performed by using the disc diffusion agar method [5]. Petri dishes were first inoculated with microbes by pipetting the microbial suspension onto the agar. The standardized microbial suspension was applied onto the solidified agars by using sterile cotton swabs and allowed to dry for 10 minutes. Crude extract impregnated discs were aseptically transferred on the inoculated agar plates and left to be incubated for $24 \mathrm{hrs}$ to 7 days. The clear zones of inhibition around the test crude extract disc were measured for any indication of antimicrobial activity. Nystatin, ampicillin and tetracycline impregnated discs were used as standard reference or positive controls and the solvents were used as negative controls. All assays were carried out in triplicate.

\section{Minimum Inhibitory Concentration (MIC)}

The MIC determination of the crude extracts was referred and modified from $[4,6] .30 \mu \mathrm{L}$ samples were diluted by two fold serial dilution with its suitable solvent in the wells of microtiter plate. $170 \mu \mathrm{L}$ of the prepared microbial culture was added to each well to give a final volume of $200 \mu \mathrm{L}$ with final concentrations of each well ranging from 50 $\mathrm{mg} / \mathrm{mL}$ to $0.024 \mathrm{mg} / \mathrm{mL}$. The microtitre plates were then incubated at $30^{\circ} \mathrm{C}$ to $37^{\circ} \mathrm{C}$ for 24 to 48 hours, with their upper surface covered and sealed with parafilms. After incubation, $20 \mu \mathrm{L}$ of MTT solution was pipette into the wells for indication of growth. The lowest concentration that did not show any visible growth was recorded as the MIC of that extract for the tested microbial species. All the MIC experimentations were performed in triplicate.

\section{RESULTS AND DISCUSSION}

\section{Antimicrobial Activity}

The results for the antimicrobial activity test of different crude solvent extracts of $A$. indica are displayed in Table $\mathbf{1 .}$ The growth of both Staphylococcus aureus, and Candida albicans can be seen to be inhibited by chloroform stembark, methanol stembark and leaves extract in a concentration dependent manner but not inhibited by the petroleum stembark extract. While Pseudomonas aeruginosa, Escherichia coli and Tricophyton tonsurans were shown to be resistant towards all type of extracts that was studied in this research. C. albicans seems to be more susceptible 
Table 2. MIC Determination of Acalypha Indica Active Crude Extracts Against Candida Albicans

\begin{tabular}{|c|c|}
\hline Extracts & MIC $(\mathbf{m g} / \mathbf{m L})$ \\
\hline \hline Chloroform (stembark) & 0.938 \\
\hline Methanol (stembark) & 0.469 \\
\hline Methanol (leaves) & 0.469 \\
\hline
\end{tabular}

MIC: Minimum Inhibitory Concentration

towards $A$. indica stembark when compared to $S$. aureus while the $S$. aureus was more susceptible towards the leaves extract when compared to C. albicans. All microbes were susceptible to its respective positive control. Both $S$. aureus and E.coli were susceptible to ampicillin while $P$. aeruginosa was susceptible to its positive control, tetracycline. In the terms of the dermatophytes group, both $C$. albicans and T. tonsurans were susceptible to nystatin.

According to the study, all tested microorganisms were resistant towards petroleum ether crude extract of $A$. indica stembark which could indicate that the extract does not contain active compounds that could be responsible for antimicrobial activities. It is also noted that all Gramnegative bacteria were more resistant towards all the extracts tested compared to the Gram-positive bacteria. According to a study conducted by [7], A. indica extracts produced active results against all the Gram-positive bacteria tested while one of the Gram-negative bacteria, Pseudomonas aeruginosa was only susceptible towards the extracts at a higher concentration. This result could be attributed to the difference in wall compositions that exist in both Gram-positive and Gramnegative bacteria. While the Gram-negative bacteria possess wall that consists of lipopolysaccharide layer along with proteins and phospholipids that may impede the entry of active compounds of $A$. indica crude extracts, the Gram-positive bacteria contains a very active area of cell metabolism called periplasmic space that carry many digestive enzymes and transport proteins which could attribute to the susceptibility of the microorganisms.

In the aspect of its antifungal properties, the plants extract prove to be active against fungi Candida albicans in increasing concentration compared to Tricophyton tonsurans. Previous antifungal studies conducted by $[8,9]$ proved that methanol extract of $A$. indica possess antifungal activity against $C$. albicans. However, their studies involve the use of the whole plant and not a specific part of the plant. Another study from [10] has also showed that the methanol leaves extract of $A$. indica is most active against $C$. albicans compared to other extracts tested as it resulted in the highest inhibition zones against fungi. C. albicans was also proven to be susceptible towards chloroform and ethanol extracts compared to other fungi in a study conducted by [11].

\section{Minimum Inhibitory Concentration}

As it is showed in Table 2, both methanol stembark and leaves extract recorded a strong MIC value of $0.469 \mathrm{mg} / \mathrm{mL}$ in which the growth of $C$. albicans was inhibited while the chloroform stembark extract was recorded to possess a medium MIC value of $0.938 \mathrm{mg} / \mathrm{mL}$.

The antimicrobial activity could be attributed to the presence of alkaloids, tannins and saponins in the $A$. indica leaves extract according to [12]. This was also supported by [13] with additional compounds that were discovered such as steroids, cardiac glycosides and phenols. One study by [14] suggested that the antibacterial activity of Acalypha indica leaves extract could be attributed to the active compounds of alkaloids and tannins. According to a study conducted by [15], the presence of bioactive compounds such as alkaloids, tannins, steroids, saponins, flavanoids, glycosides and phenolic compounds was also detected during it phytochemical testing.

\section{CONCLUSION}

In conclusion, the present study indicates that the crude extract of $A$. indica stembark and leaves possess some antimicrobial activities against certain pathogenic microbes. The extracts of methanol and chloroform proved to be a good antifungal agent against Candida albicans. Nevertheless, future studies in regards to its bioactive compound should be done in order to identify the compound that is responsible for its antimicrobial activities.

\section{CONFLICT OF INTEREST}

This academic work is funded by Ministry of Higher Education (MOHE) under the fundamental research grant scheme (FRGS 11-036-0185).

\section{ACKNOWLEDGEMENTS}

The authors wish to express their gratitude to Kulliyyah of Pharmacy, Kulliyyah of Science, IIUM and Ministry of Higher Education (MOHE) for financial support (FRGS with project no: 11-036-0185) in completing this current research works.

\section{REFERENCES}

[1] Schmelzer, G.H.; Gurib-Fakim, A. Acalypha indica L. Record from Protabase. PROTA Plant Resources of Tropical Africa / Ressources végétales de l'Afrique tropicale, Wageningen, Netherlands. Available from: http://www.prota4u.org/protav8.asp?h=M4\&t=Acalypha\&p=Acalypha+indica\#Synonyms

[2] Masih, M.; Banerjee, T.; Banerjee, B.; Pal, A. Antidiabetic activity of Acalypha indica linn. On Normal and Alloxan Induced Diabetic Rats. Int. J. Pharm. Pharm. Sci., 2011, 3(3), 51-54.

[3] Vijayabhaskar, K.; Venkateshwarlu, G.; Bhaskar, J.; Sravanprasad, M.; Sathis, K.D.; Suresh, K.P.; Somsubhara, G. Evaluation of effect of Acalypha indica linn. leaves lxtract on bronchodilation and bronchial hyperreactivity in experimental animals. J. Pharm. Res., 2011, 4(7), 2250-2253.

[4] Lalitha, M. K. Manual on antimicrobial susceptibility testing. (2005): [about 47pp] Available from: http://www.ijmm.org/documents/Antimicrobial.doc.

[5] Bauer, A.W., Kirby W. M. J. C., Jurk, M. Antibiotic susceptibility testing by a standardized single disc method. Am. J. Clin. Pathol., 1966, 45, 493-496

[6] Wiegand, I.; Hilpert, K.; Hancock, R. E. Agar and broth dilution methods to determine the minimal inhibitory concentration (MIC) of antimicrobial substances. Nat. Protoc., 2008, 3(2), 163-175.

[7] Govindarajan, M.; Jebanesan, A.; Reetha, D.; Amsath, R., Pushpanathan, T.; Samidurai, K. Antibacterial activity of Acalypha indica L. Eur. Rev. Med. Pharmacol. Sci., 2008, 12, 299-302.

[8] Suresh, M.; Rath, P.K.; Panneerselvam, A.; Dhanasekaran, D.; Thajuddin, N. Antifungal activity of selected Indian medicinal plant salts. J. Glob. Pharm. Technol., 2009, 2(4), 71-74.

[9] Kanimozhi, D, Ratha bai, V. and Baskaran, C. Evaluation of anti microbial activity of Acalypha indica. Int. J. Res. Pharm. Sci., 2012, 2(1), 129-137.

[10] Solomon, R.D.; Jebakumar, S.K.; Jayaraj, V. Isolation, identification and study of antimicrobial property of a bioactive 
compound in an Indian medicinal plant Acalypha indica (Indiannettle). World J. Microbiol. Biotechnol., 2005, 21, 1231-1236.

[11] Somchit, M. N.; Rashid, R. A.; Abdullah, A.; Zuraini, A.; Zakaria, Z. A.; Sulaiman, M.R., Mutalib, A.R. In vitro antimicrobial activity of leaves of Acalypha indica linn.(Euphorbiaceae). Afr. J. Microbiol. Res., 2010, i(20), 2133-2136.

[12] Rajaselvam, J; Benila S.J.M.; Meena R. A Study of antimicrobial activity of Acalypha Indica against selected microbial species. Int. J. Pharm. Sci. Res., 2012, 3(9), 473-476.

[13] Khaleel, B.S.; Sudarshanam, G. Multiple herbal therapy antimicrobial activity of wound healing paste (Pasuru) used by
Sugali tribes of Yerramalais of Kurnool district.,Andhra Pradesh,India. Int. J. Pharm. Technol. Res., 2011, 3(3), 1238-1241.

[14] Murugan, T.; Saranraj, P. Antibacterial Activity of various solvent extracts of the Indian herbal plant Acalypha indica against human pathogens causing nosocomial infection. Int. J. Pharm. Biol. Arch., 2011, 2(5), 1473-1478.

[15] Mohan, S. C.; Dinakar, S.; Anand, T.; Elayaraja, R.; SathiyaPriya, B. Phytochemical, GC-MS analysis and antibacterial activity of a medicinal plant Acalypha indica. Int. J. Pharm. Technol. Res., 2012, 4(3), 1050-1054

(C) Ishak et al.; Licensee Bentham Open.

This is an open access article licensed under the terms of the Creative Commons Attribution Non-Commercial License (http://creativecommons.org/licenses/by$\mathrm{nc} / 3.0 /$ ), which permits unrestricted, non-commercial use, distribution and reproduction in any medium, provided the work is properly cited. 